\title{
Stereotypic image of Siberia in Russian mass media
}

\author{
Olga Kondratyeva ${ }^{1}$, Olga Valko $^{1 *}$ \\ ${ }^{1}$ Kemerovo State University, 6 Krasnaya St., 650000, Kemerovo, Russia
}

\begin{abstract}
The article studies theoretical aspects of the image of the region and their realization as exemplified by the image of Siberia. The article treats the structure of the image and mechanisms of its formation from the point of view of the cognitive approach and with the help of frame structures. The cognitive analysis enables to differentiate three levels: frame, subframes, and slots, pertaining to the entity explored. The research allows demonstrating that the stereotypical ideas play an essential role in forming and sustaining the images of regions. Mass media appear to be the main source of the stereotypic image of the region due to highlighting different facts concerning the sterotypicized phenomenon, selecting various linguistic means for featuring it and influencing the emotional and evaluative perception of the image. The study was based on the data of the National Corpus of the Russian Language, which were analyzed with the help of content analysis and frame analysis. The image of the Siberian region actively exploits the frames "Nature and Geography of Siberia", "History of Siberia", "Economy of Siberia". The research found out the dynamic and ambivalent character of the stereotypic image of Siberia.
\end{abstract}

\section{Introduction}

The currently important part of modern Russian studies is the analysis of the images of the regions represented in different types of discourse, which is conditioned by the following: (1) the images of the regions are still poorly understood, and (2) the cognitive mechanisms of the regional image formation (by direct personal experience or indirectly, for example, via materials of mass media, Internet, eyewitnesses' stories, books, films, etc.) also need a description.

The images of the regions are formed largely under the influence of stereotyped ideas about a particular territory. Most people have an idea about the regions of this country and the world even before they directly encounter them in reality; such stereotypes are being formed under the influence of an individual's sociocultural environment and allow one "to comprehend the world as a whole, thus going beyond the framework of one's narrow social, geographical, and political environment" [1].

\section{Material and methods}

Stereotypes are stable units of consciousness, which are often handed down from generation to generation; they facilitate the automatic thinking and phenomena evaluating. The term "stereotype" was introduced into the scientific use by U. Lippmann in 1922 in his book "Public Opinion" and is defined as "... a simplified, preconceived notion that does not result from one's own experience" [2]. Consequently, stereotypes arise in an indirect way. There are three stages of stereotype formation: alignment, i.e. reduction of the object to several characteristic features; strengthening, i.e. assigning a special significance to these identified characteristics; assimilation, i.e. the choice of aligned and strengthened features to construct an image that is meaningful for a person [3]. Such strengthened features do serve the basis in moulding stereotypic ideas about the region, in other words, they form its stereotypic image.

As a source of the stereotypic image of the region, in the first place we can point at the mass media that are responsible for frequent mentioning the region on their pages, describing its main features, selecting the newsworthy events to highlight, placing emphasis on information, choosing the linguistic means that have the strongest impact on the addressee, forming a certain emotional attitude to the region. The result of such mass media activities is the formation of a stereotypic media image of the region perceived by the addressees (readers, viewers, and listeners) as a kind of dogma, anchored in their minds and retransmitted later in business and everyday communication $[4,5]$.

One of the most interesting in this respect is the image of Siberia, which is associated with a significant number of stereotypes [6-11]. Mass media played an essential role in the formation of these stereotypes.

The objective of the proposed study is to analyze stereotyped ideas about Siberia contained in the Russian media discourse of the $21^{\text {st }}$ century and to identify the linguistic means used by the media to form and transmit these stereotypes. The material of the study includes the texts of the Russian mass media of the $21^{\text {st }}$ century, presented in the National Corpus of the Russian Language. The main methods of the study were content

\footnotetext{
* Corresponding author: olgav2001@gmail.com
} 
analysis and frame analysis, which consist in presenting the stereotypic information about Siberia in the form of frames (knowledge structures) and their components subframes and slots $[7,12]$.

\section{Discussion}

Examining Russian media texts has allowed explicating the frame-and-slot structure of the stereotypic media image of Siberia, created by the Russian mass media in the recent century; it has been established that the mass media extensively exploit the frames "Nature and Geography of Siberia", "History of Siberia", "Economy of Siberia".

\subsection{Frame 1. "NATURE AND GEOGRAPHY OF SIBERIA"}

Most frequently, Siberia's characterization in the Russian mass media is carried out by accentuating the unique natural and geographical peculiarities of the region.

\subsubsection{Subframe 1. "Characteristics of the territory"}

Within this framework, the Russian mass media focus readers' attention on the geographical position of the region, its remoteness from the administrative centre of the country and other countries, the large area of the region, its sparse population.

Slot 1.1. “Geographical position”. Quite often Russian mass media point out the fact that for many people the territorial position of Siberia is still a mystery:

Как сказал А. Соколов, иногда дешевле съездить в Туриию, чем отправиться в Екатеринбург, "поэтому у многих москвичей представление, что за МКАД начинается Сибирь” (Izvestia, 2013) / As A. Sokolov said, sometimes it's cheaper to go to Turkey than to travel to Yekaterinburg, "that is why many Muscovites have the idea that Siberia starts outside the Moscow Ring Road" (Izvestia, 2013).

Я пошлю господину Дэйли атлас. Пусть посмотрит, где начинается Сибирь. У нас авиационное сообщение в стране превосходно налажено. Они у себя в Северной Америке дольше u дальие летают. По логистике, конечно, целесообразнее провести встречи с энхаэловцами в европейской части России. Хотя до того же Омска два с половиной часа лета с ветерком. Смешное расстояние! (Soviet sport, 2011). / I will send Mr. Dayley an atlas. Let him see where Siberia begins. We have an excellent air service in the country. They travel by air in North America longer and farther. According to logistics, of course, it is more expedient to hold meetings with the NHL guys in the European part of Russia. On the other hand, it takes just two hours and a half to get to Omsk. Is it a distance to dread? (Soviet sport, 2011).

Both contexts, containing representations by both the inhabitants of Moscow and America, demonstrate stereotypical ideas about the location of Siberia, which do not correspond to the reality.

Slot 1.2. "Remoteness of the territory". Inaccurate ideas about the location of Siberia are largely associated with stereotypic ideas about the remoteness of the region from both Moscow and the world. Such representations are embodied in the lexemes and word combinations like далекий / far (adj), далеко/ far (adv), конеи мира / the world's end, край cвеma / the edge of the world, Тьмутаракань / Tmutarakan (at the back of god-speed, miles from nowhere) and others:

За границей, собираясь в Сибирь, ты думаешь, что это конец мира и ни один человек по доброй воле не захочет там жить (Komsomolskaya Pravda, 2012) / Abroad, when you are going to Siberia, you think that this is at the end of nowhere and no one will voluntarily choose to live there (Komsomolskaya Pravda, 2012).

Овечкин: Бэттмана пугает, что лететь в Сибирь далеко? Лететь в Лос-Анджелес в два раза дольше! (Soviet sport, 2011) / Ovechkin: Is Batman scared that it is so far to fly to Siberia? Flying to Los Angeles is twice as long! (Soviet sport, 2011).

Не говоря уже о том, чтобы отправиться в "Тьмутаракань» - Урал, Сибирь, на Дальний Восток.... (Izvestia, 2012) / Still less going to a Godforsaken place - Ural, Siberia, the Far East ... (Izvestia, 2012).

Slot 1.3. "Large area of the territory". One of the frequent characteristics of Siberia, engrained in people's minds, is the huge area of the region. Such stereotypic representations are expressed by the lexemes большой / large, огромный / huge, бескрайний / endless, and others:

Мне хотелось сказать ему о том, какая же бескрайняя наша Сибирь и Россия, но зачем ozopyamb? (Komsomolskaya Pravda, 2013) / I wanted to tell him about how vast our Siberia and Russia are, but why upset him? (Komsomolskaya Pravda, 2013).

Огромная Сибирь с ее нефтью (Komsomolskaya Pravda, 2013) / Spacious Siberia with its oil (Komsomolskaya Pravda, 2013).

Slot 1.4. “Uninhabited, undeveloped territory". Widespread ideas of the considerable territory, occupied by Siberia, largely predetermine the concept of scarcity of people in the territory, since it is hard to imagine such a vast space to be densely populated. These stereotypical representations can be observed in the lexemes: малолюдный / scarcely populated, необитаемый / uninhabited, безжизненный / lifeless, пустынный / deserted, and others:

А выше нее темнота, словно бы Сибирь и Север с Чукоткой необитаемы вовсе (Komsomolskaya Pravda, 2012) / Above it there is darkness, as if Siberia, North and Chukotka are absolutely uninhabited (Komsomolskaya Pravda, 2012).

До 2015 года общественное мнение вяло беспокоилось «демографическим навесом» Азии над малолюдными территориями Сибири и Дальнего Востока (Km.ru, 2015) / Till 2015 the 
public opinion was little concerned with "demographic prevalence" of Asia over scarcely populated territories of Siberia and the Far East (Km.ru, 2015).

A значительная часть российской территории Нечерноземье, Русский Север, Сибирь буквально выммupaюm (Izvestia, 2013) / A considerable part of the Russian territory - non-Black Earth Belt, Russian North, Siberia - are literally dying out (Izvestia, 2013).

\subsubsection{Subframe 2. "Climate"}

This sub-frame in the analyzed material is the second in frequency. Siberia is traditionally considered as one of the coldest places in the world, a peculiar realm of frost, cold, ice, and snow.

Slot 2.1. "Frost and cold". Stereotypic representations create the image of Siberia as a region of low temperatures, where frost and cold are permanent, no matter what the time of the year is at the moment. Representatives of the above-mentioned stereotypes are the words: холод / cold (nоиn), холодно / cold (adv), мороз / frost (noun), замерзать / freeze, вечная мерзлота / permafrost, etc.

Еще сльшиали про Сибирь, что там холодно (Komsomolskaya Pravda, 2014) / We also heard about Siberia that it is cold there (Komsomolskaya Pravda, 2014).

Единственное, что я знала о Сибири до приезда сюда, это то, что здесь невероятно холодно (Izvestia, 2014) / The only thing I knew about Siberia before coming here is that it is incredibly cold here (Izvestia, 2014).

Когда кто-то предложил мне спеть в Сибири, я ответила: «Ни за что, там такой мороз!» (Izvestia, 2014) / When someone invited me to sing in Siberia, I answered: "No way, it's so frosty there!" (Izvestia, 2014).

Mы привыкли думать, что вечная мерзлота это про Сибирь, Антарктиду или Гренландию (Komsomolskaya Pravda, 2011) / We are used to thinking that permafrost is about Siberia, Antarctica or Greenland (Komsomolskaya Pravda, 2011).

It is noteworthy that such ideas are shared by people who have never been to Siberia, which is fixed in media texts with the help of special markers - сльшиали / heard, знала до приезда / knew before coming, привыкли думать / they used to think, etc. (see the above contexts).

Slot 2.2. "Snow and ice. The low temperatures of Siberia naturally result in water transforming into snow and ice in the given territory. The most frequent linguistic representatives are снега / snow(s) (noun), заснеженный / snow-covered, метель / snowstorm, лед / ice, etc.:

Он тепло приветствовал участников фестиваля и высказал слова особой благодарности мировым звездам, многие из которых прилетели в снега Сибири из далеких солнечных стран, покинув лазурные берега под кипарисами и пальмами
(Trud-7, 2008) / He warmly welcomed the festival participants and pronounced the words of special gratitude to the world stars, many of whom had flown from distant sunny countries into the Siberian snows, having left the azure coasts under cypresses and palms (Trud-7, 2008).

«Участники будут пугать друг друга и странучастниц российским танками, сибирским льдами и др.» - спрогнозировал Воронин (Point.md, 2018) / "Participants will frighten each other and the participating countries with Russian tanks, Siberian ice, etc.," Voronin predicted (Point.md, 2018).

It should be noted that many representatives pointing to the climatic characteristics of Siberia are used in the plural form (for example, холода / colds, морозы / frosts, снега / snows, льды / ices, etc.), which indicates the frequency of such weather phenomena and their maximum degree of manifestation.

\subsubsection{Subframe 3. "Natural and climatic zones"}

Siberia stereotypically appears as a territory covered with dense forests, mostly coniferous (taiga); in some people's minds, Siberia and Taiga are synonyms to some extent:

В итоге махнул на меня рукой: «Ладно, Маш, я в Сибирь поеду, в тайгу (Soviet sport, 2011) / As a result, he gave up on me: "Okay, Masha, I'm going to Siberia, to the taiga” (Soviet sport, 2011).

Куда, можно узнать? В тайгу, в Сибирь (Komsomolskaya Pravda, 2012) / Where, can you tell me? To the taiga, to Siberia (Komsomolskaya Pravda, 2012).

\section{Subframe 3.1.4 "Fauna"}

The territory of Siberia appears to be inhabited by a variety of animals, the most common of which are bears and wolves:

Инциденты с медведями и волками чаще всего
случаются в Сибири и на Дальнем Востоке
(Izvestia, 2018) / Incidents with bears and wolves
most often happen in Siberia and in the Far East
(Izvestia, 2018).
Сибирские медведи атакуют села. Из-за
аномально холодной весны им нечего есть (Taiga-
info, 2018) / Siberian bears attack villages. Because
of the abnormally cold spring, they have nothing to
eat (Taiga-info, 2018).

\subsection{Frame 2. "HISTORY OF SIBERIA"}

Characterizing Siberia, mass media regularly recall historical events, which made a significant impact on the region's future and influenced the formation of its image, and make references to the historical characters associated with the Siberian region in the minds of Russians.

\subsubsection{Subframe 1. "Place of migration"}


Relevant for the characteristics of Siberia is the idea of the region as a place where the inhabitants of other regions of Russia, who had come there as a result of migration (involuntary or voluntary), have been dominating over the indigenous population for a long time.

Slot 1.1. "Place of exile". Despite the fact that since the $80 \mathrm{~s}$ of the $20^{\text {th }}$ century, Siberia is no longer a place of exile, and according to the information from open sources, the number of prisons in Siberia is significantly fewer than the number of prisons in the European part of Russia, the image of Siberia as a place of exile has firmly fixed in the mind [7] and these stereotypes are quite alive so far:

Ну и главное, чтобы создателей фильма в Сибирь не сослали (RBC Daily, 2014) / And the main thing is that the filmmakers will not be exiled to Siberia (RBC Daily, 2014).

Я схватил ее за руку под столом: «Замолчи, или ты хочешь, чтобы нас сослали в Сибирь?» (Komsomolskaya Pravda, 2013) / I grabbed her hand under the table: "Shut up, or do you want us to be exiled to Siberia?" (Komsomolskaya Pravda, 2013).

Linguistic representatives for these stereotypic ideas about the region are the words: ссылка / exile (noun), сослать / exile (verb), закатать / lock ир, загнать / send up the river, этапировать / convoy (transport under guard), тюрьма / prison, каторга / forced-labor caтр, кандаль / shackles, иепи / chains, etc.:

Вскоре его сослали в Сибирь, а она добровольно последовала за ним в ссылку (Komsomolskaya Pravda, 2014) / Soon he was exiled to Siberia, and she voluntarily followed him into the exile (Komsomolskaya Pravda, 2014).

Они пустили «красного петуха» помещику, который издевался над людьми, и их отправили всех пешком за восемь $с$ половиной тысяч километров, в цепях и кандалах в Сибирь (Komsomolskaya Pravda, 2013) / They set fire onto the landlord who maltreated people, and they all were sent to Siberia, eight and a half thousand kilometers away, on foot in chains and shackles (Komsomolskaya Pravda, 2013).

В Сибирь попадали, в лукьяновскую тюрьму попадали, на тот свет попадали (Izvestia, 2013) / They fell into Siberia, they fell into Lukyanov's Prison, they fell into the next world (Izvestia, 2013). «К слову - относительно россказней: мол, мой прадед в политику не лез, жил себе, пасеку завел, а проклятые коммунисты в 1939 году его в Сибирь закатали ...» (Komsomolskaya Pravda, 2013) / "By the way - as for the nonsense stories: they say, my great-grandfather did not meddle in politics, he lived by himself, set up an apiary, and the damned communists sent him out into Siberia in 1939 ..." (Komsomolskaya Pravda, 2013).

Slot 2.2. "Place of migration". In the mass media, the growth of the Siberian population is also traditionally associated with the resettlement of peoples in the Stalin era and with the evacuation of enterprises and their workers to the rear during the war. Representatives of this slot are lexemes: переселить / to relocate, переселение / relocation, депортировать / deport, депортация / deportation, colonize, colony, migration, evacuation, etc.:

Одним из способов наделения землей правительство выбрало путь переселенческой политики в Сибирь (RIA News, 2010) / The government has chosen the policy of resettlement to Siberia as a way to endow with land (RIA News, 2010).

Мол, местные евреи «помогали Москве советизировать оккупированную Литву», участвовали в предвоенной депортации в Сибирь некоторых представителей населения страны (Komsomolskaya Pravda, 2012) / They say, local Jews "helped Moscow to sovietize the occupied area of Lithuania", participated in the pre-war deportation of some citizens to Siberia (Komsomolskaya Pravda, 2012).

При этом русские - как испанциы, французы и англичане - колонизировали Сибирь, массово переселяясь на новые территории и состав там большинство населения (Komsomolskaya Pravda, 2013) / At the same time, Russians - like Spaniards, the French and the English - colonized Siberia, moving massively to new territories and making up the majority of the population there (Komsomolskaya Pravda, 2013).

Но ночью партизаны вывезли, спасли. Потом эвакуация в Сибирь (Komsomolskaya Pravda, 2012) / But at night the guerrillas took them out, rescued them. Then the evacuation to Siberia took place (Komsomolskaya Pravda, 2012).

\subsubsection{Subframe 2. "Historical personalities"}

Considering the history of Siberia, the media regularly mention historical personalities whose activities are relevant for the formation and development of the region. The most frequent are the references to Tsar Ivan the Terrible, Ataman (chieftain) Ermak and Minister Stolypin. Their activities, directed to the development of Siberia, are described by the verbs присоединить / to join, завоевать / to conquer, открыть / to open, присоединить / to relocate, etc.:

А ведь Грозный вдвое расширил территорию России, присоединил столько земель. Сибирь, например (Komsomolskaya Pravda, 2013) / But Ivan the Terrible doubled the territory of Russia, annexed so many lands. Siberia, for example (Komsomolskaya Pravda, 2013).

Кстати, само завоевание Сибири Ермаком классический пример успешного государственночастного партнерства (Komsomolskaya Pravda, 2012) / By the way, the very conquest of Siberia by Ermak is a classic example of a successful publicprivate partnership (Komsomolskaya Pravda, 2012). Ax да, ещче пишут, как Ермак открыл Сибирь (Komsomolskaya Pravda, 2013) / Oh, by the way, they also write about how Ermak discovered Siberia (Komsomolskaya Pravda, 2013). 
И Столыпин сделал гениальную вещьь. Призвал крестьян ехать в Сибирь. Создал банк, который давал переселенцуам фактически беспроцентный кредит (Komsomolskaya Pravda, 2011) / And Stolypin did a brilliant thing. He called on the peasants to go to Siberia. He created a bank, which gave migrants a virtually interest-free loan (Komsomolskaya Pravda, 2011).

\subsection{Frame 3. "ECONOMY OF SIBERIA"}

The stereotypes associated with the economy of Siberia are quite contradictory. The basis of the Siberian economy is the natural resources, the extraction and export of which the region is engaged in.

\subsubsection{Subframe 1. "Natural resources"}

Siberia is traditionally considered the largest resource center in Russia, which concentrates rich natural resources and minerals.

Slot 1.1. "Types of natural resources". Representations of Siberian rich resources are transferred with the help of both generic nominations (природные богатства / natural resources, полезные ископаемые / minerals, cыpьe, / raw materials, месторождения / deposits, etc.) and their specific names (уголь / coal, газ / gas, нефть / oil, золото / gold, самоиветь / gems, etc.):

В те самые годы вся западная Сибирь стала ударной стройкой - осваивались новые месторождения, ставшие основой богатств нынешних олигархов (Komsomolskaya Pravda, 2011) / In those same years, the whole of Western Siberia became a shock construction site - new deposits were developed, which became the basis of the wealth of the current oligarchs (Komsomolskaya Pravda, 2011).

Как утверждают инициаторы акции, сегодня Сибирь рассматривается государством преимущественно как сырьевая колония (New Region 2, 2010) / According to the initiators of the action, today the state considers Siberia mainly as a raw material colony (New Region 2, 2010).

Slot 1.2. "Siberia as a Resource Center of Russia". For a long time, Siberia has been perceived as a raw material appendage of the country, from which all the wealth was pumped to the capital and distributed throughout the country. Such stereotyped representations are delivered by combinations: сырьевой придаток / raw material appendage, сырьевая колония / raw material colony, экономическая колония / есопотіс colony, etc.:

... Сибирь рассматривается государством преимущественно как сырьевая колония, а существующие программы развития сибирских регионов конкретного ощутимого результат не дают (New Region 2, 2010) / ... Siberia is viewed by the state mainly as a raw material colony, and the existing programs for the development of the
Siberian regions do not give a tangible result (New Region 2, 2010).

... Сибирь и дальний Восток, которые используются как экономическая колония, откуда получается большая часть доходов бюджета и которые индустриализируются $u$ теряют жителей (Komsomolskaya Pravda, 2013) / ... Siberia and the Far East, which are used as an economic colony, where most of the budget revenues come from and which are being industrialized and losing inhabitants (Komsomolskaya Pravda, 2013).

Сибирь же осталась территорией России, и благополучие всей страны прирастало ее богатствами (Komsomolskaya Pravda, 2013) / Siberia has still remained the territory of Russia, and the welfare of the whole country has been growing with its wealth (Komsomolskaya Pravda, 2013).

Slot 1.3. "Control over the natural resources of Siberia". In addition to explicating traditional ideas about Siberian riches, the Russian mass media are actively discussing a rather new problem - the problem of control over these resources and, consequently, the preservation of Siberia as a part of Russia. There is a concern about whether the inhabitants of the Siberian region, sufficiently well-off in resource terms, will be striving to separate into an independent economic and political entity:

За горячими южными парнями потянутся богатые природными ископаемыми Якутия, Сибирь, «плюнут на материк» Дальний Восток и Кольмма (Komsomolskaya Pravda, 2011) / The hot southern guys will be followed by regions rich in natural fossils - Yakutia, Siberia; the Far East and Kolyma "give up on the mainland" (Komsomolskaya Pravda, 2011).

The mass media also discusses the opposite view, that Russia can sacrifice Siberia to solve geopolitical issues:

Как в свое время продали Аляску, сейчас nродадуm Сибирь (Izvestia, 2013) / As they once sold Alaska, they will now sell Siberia (Izvestia, 2013).

Думаю, что наши главнье сдадут Сибирь, сдадут Куриль, сдадут Сахалин японияам (Izvestia, 2013) / I think that our bigshots will cede Siberia, they will cede the Kurile Islands, they will cede Sakhalin to the Japanese (Izvestia, 2013).

Сейчас идут какие-то странные предложения давайте отдадим Дальний Восток, Кавказ, Сибирь, - возмущался Зюганов (Komsomolskaya Pravda, 2013) / Now there are some strange proposals - let's relinquish the Far East, the Caucasus, Siberia, - Zyuganov says indignantly (Komsomolskaya Pravda, 2013).

In addition, the claims of foreign states to Siberia stemming from the resource riches of the region are rather actively discussed:

Евросоюз требует от России допустить его к разработке природных ресурсов Сибири (Komsomolskaya Pravda, 2012) / The EU demands that Russia admit it to developing natural 
resources of Siberia (Komsomolskaya Pravda, 2012).

Помните фразу госсекретаря США Мадлен Олбрайт о том, как несправедливо, что одна страна распоряжается таким богаством, как Cибирь? (Komsomolskaya Pravda, 2012) / Do you remember the words by Madeleine Albright, the US Secretary of State, that it is highly unfair that one country controls such richness as Siberia? (Komsomolskaya Pravda, 2012).

Сибирь с ее природными ресурсами не должна находиться под контролем Москвы (New Region 2, 2010) / Siberia with its natural resources should not be under Moscow's control (New Region 2, 2010).

Да у всех мировых завоевателей идея закрепить свою победу путем расчленения России, чтобы она своими размерами не пугала других. И, конечно, надо взять будет под внешний контроль природные ресурсы России, Сибирь, газ и нефть (Izvestia, 2014) / Actually all world conquerors have the idea to confirm their victory by dismembering Russia, so that it does not frighten others by its size. And, of course, it is necessary to take under external control Russia's natural resources, Siberia, gas and oil (Izvestia, 2014).

The European Union, the United States, China and Japan are regularly referred to as main claimants for the riches of Siberia.

The widespread assumptions about the possible loss of the wealth of Siberia and the region itself cause concerns both among the inhabitants of Siberia and the majority of Russians who are interested in preserving the country's strategic resources and its territorial integrity.

\subsubsection{Subframe 2. "The state of Siberia's economy"}

The economic situation in Siberia is largely determined by its rich natural resources, which are both a blessing and a "curse" of the region.

Slot 2.1. "Stagnation of the economy". The natural and resource capital is a potentially dangerous factor, as it attracts the interest of other states, and also leads to stagnation, as revenues from the export of raw materials allow the authorities not to care about the development of the economy, turn the region into a commodity colony (see slot 1.2 described above) which leads to a decrease in the standard of living and, accordingly, to a stable perception of the region as depressive. Such stereotyped ideas are represented in mass media by such lexemes and combinations as стагнация / stagnation, депрессивный регион / depressive region and others:

18 устойчиво депрессивных регионов (Сибирь, Дальний Восток и Центральная Россия) должны разработать стратегии развития и подать заявки (РБК Дейли, 2012) / 18 permanently depressive regions (Siberia, the Far East and Central Russia) should work out development strategies and submit applications (RBC Daily, 2012).
Slot 2.2. "Development of economy". In the Russian media of the $21^{\text {st }}$ century, there is an active desire to form an idea of Siberia as a region whose economy is entering a phase of active development, which should result in intensive evolution of the region and an improvement in the living standards of its inhabitants. Similar ideas are designated by such lexemes and combinations as pазвитие / development, развивать / develop, pocm / growth, экономические мощности / economic capacity, приоритетный регион / priority region, and others:

Понятно, что надо развивать Сибирь и Дальний Восток (RBC Daily, 2013) / It is clear that we need to develop Siberia and the Far East (RBC Daily, 2013).

Новыми точками роста российской экономики должнны стать Дальний Восток, Сибирь, Юح России и Калининградская область (Komsomolskaya Pravda, 2013) / New growth points of the Russian economy should become the Far East, Siberia, the South of Russia and the Kaliningrad Region (Komsomolskaya Pravda 2013).

Сергей Миронов убежден, что Сибирь и Дальний Восток способны создать экономические мощности, сопоставимые по масштабу с бурно развиваюшимися экономиками Китая и ЮгоВосточной Азии (RBC Daily, 2013) / Sergei Mironov is convinced that Siberia and the Far East are able to create economic capacities comparable in scale to the booming economies of China and South-East Asia (RBC Daily, 2013).

Владимир Путин поставил задачу за десять лет сделать Сибирь местом, по-настоящему пригодным для жизни и привлекательным для paботы (Izvestia, 2010) / Vladimir Putin set the task for 10 years to make Siberia a place that is really suitable for life and attractive for work (Izvestia, 2010).

\section{Conclusion}

The analysis made it possible to establish that the stereotypic image of Siberia, presented on the pages of the Russian mass media of the new century, includes the frames "Nature and Geography of Siberia", "History of Siberia", "Economy of Siberia", which are closely interrelated and form a significant number of stereotypes about the region. At the same time, there are practically no stereotypes about Siberia related to the frames "Culture", "Science", "Sport". Such organization of stereotypic image shows that Siberia is perceived primarily as a region whose status is determined by objectively developed circumstances - its geographical location, size, climate and natural resources, it is these factors that determined its history and the current state of the economy and social environment. Circumstances, formed intentionally (achievements in culture, science and sport), have not yet become the characteristics that form the recognizable image of the region in the eyes of Russians and the world community, therefore, serious 
work in this direction is necessary to create a positive image of Siberia.

The analysis also demonstrated that the stereotypic image of Siberia is dynamic. The media reflect the stereotypes traditionally existing in the minds of a significant number of people (residents of other Russian regions and foreigners). They feature Siberia as a remote, vast region with a harsh climate, raw materials appendage of Russia rich in natural resources, which is also a place of exile and hard labour internally displaced people. At the same time, the Russian mass media are beginning to form a new stereotypic image of Siberia, an image of the region that is both a pledge for Russia's development and an object of claims from unfriendly countries.

The stereotypic image of Siberia presented in the media is ambivalent, some of the existing stereotypes have a pronounced negative character (stereotypic components "далеко" / "far away", "холодно" / "cold", “безлюдно" / "deserted”, “волки и медведи” / "wolves and bears", “лагеря и тюрьмы" / "camps and prisons") and cause feelings of anxiety, while some of the stereotypes, mostly new ones, are neutral or positive (“большая территория" / "large territory", “природные богатства" / "natural wealth", “перспективы развития" / "development prospects") and cause interest in the region, including potential investors.

Thus, the mass media are able not only to maintain and strengthen existing stereotypes about the region, but also to create and deliver new ones, forming a voluminous, multi-level stereotypical media image of Siberia, which is the starting point for further formation of the brand and image of the Siberian region.

The research was carried out with the financial support of the RFBR Foundation and the Administration of Kemerovo Region, project No. 18-412-420003 p_a "Kuzbass: Complex cognitive-discursive study of the image of the region."

\section{References}

1. S. M. Andreeva, Wang Qi, The concept of stereotype in the context of modern research (2010). Retrieved from: http://www.confcontact.com/ 2010alyans/fl4_andree.php

2. W. Lippman, Public Opinion (New York: The Free Press, 1922).

3. G. S. Melnik, Mass-media: psychological processes and effects (St. Petersburg: Publishing house of the St. Petersburg University, 1996).

4. D. Mackie, D. Hamilton, Affect, Cognition and Stereotyping (Academic Press, 2014).

5. R. Guadagno, Psychological Processes in Social Media (Academic Press, 2019).

6. The Images of Siberia 2008: The images of Siberia (Novosibirsk: FSPI "Trends", 2008).

7. M. V. Terskikh, E. D. Malenova, Man in the world of culture. 3, 5-40 (2015).

8. O. N. Kondratyeva, N. I. Frolova, Psycholinguistics. Психолінгвістика. Психолингвистика. 24(2), 7897 (2018).

9. O. V. Felde, Tomsk State University Journal. Phylology, 3, 59-64 (2011).

10. O. V. Felde, Psycholinguistics in the 21 st centuary, 248-249 (2009).

11. I. V. Saveleva, N. V. Melnik, Journal of Siberian Federal University. Humanities \& Social Sciences, 12(1), 137-154 (2019).

12. I. A. Sushnenkova, Linguocognitive study of regional image (on the example of the Omsk region) (Omsk, 2011). 